TITLE: PROSPECTS FOR PION AND RAON FACTORIES

AUTHOR(S): Darragh E. Nagle

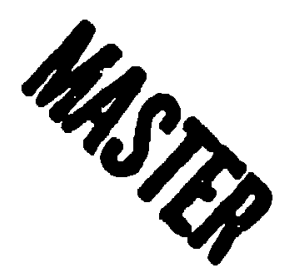

SUBMITTED TO: Particle Accelerator Conference,

Washington, DC, March 11-13, 1981

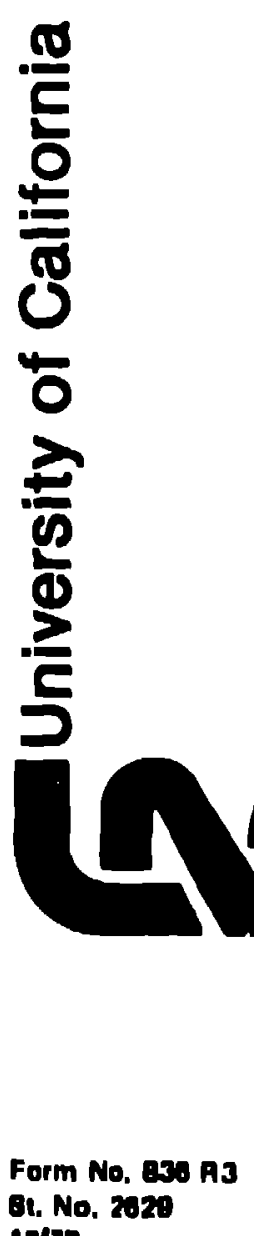

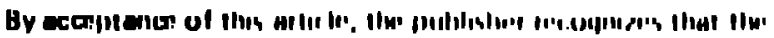

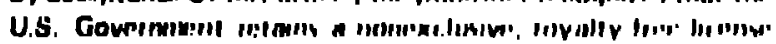

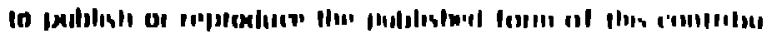

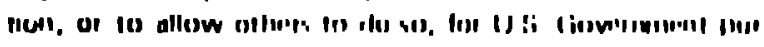
ImWers

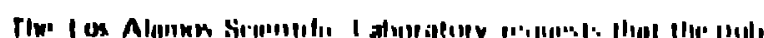

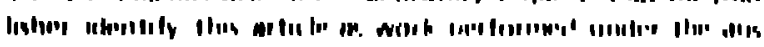

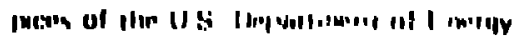




\title{
PROSFECTS FOR PION AND KAON FACTORIES
}

\author{
Darragh E. Nagle \\ Lor Alamos National Laboratory \\ Los Alamos. New Mexico 87545
}

"PION FACTORY" 1o conoonly underacood to mean an accelerator which produces a proton beam of at least 100 uA gverage current, at an enorgy above $400 \mathrm{MeV}$. Three facilitiea, nawely LAMP, SIN, and TRIUMF are in operation, and a fourth is being conetructed near Moscow. These beam Intengities are several orders of magnitude wore than for the aynchrocyclotrons which they replaced. The secondary beams of pione produced are certainly of primary interest, but also important have been the beems of protona and neutrons, muons, and fluxes of noutrinos avallable.

A number of apecialized beamp have grown up around these facilitiea. They Include chopped proton and neutron beamb, surface muon beame, polarized proton and neutron beams, etc. The LAMPF beam atop 18 a mource of - lectron neutrinos with a flux of $25 \times 10^{7} \mathrm{v} / \mathrm{e}-\mathrm{cm}^{2}$ at a diatance of $B$ metera and a primary proton current of $1 \mathrm{~mA}$. (Actual proton beams at the dump are preaently about $400 \mathrm{m.}$.) High revolution epectrometere for $p$ nucleus raaction, for $\pi$-aingle and duuble charge exchange reactions, for piontc and muonic atomic are in use. Large detectora for rare decay aearches, for neutrino studiea, etc., have been bullt and operated.

That the diacipline of medium-energy ecience is thriving an a reault of all these activities ia documented by the wany recent conferencea on t.1gh-energy physics and nuclear utructure, specialized conferences, and monographs.

\section{LAMPF Improvenente}

The mafor addition planned for the near-term at LAMPF 18. proton otorage rlug for BOO-MaV protons, which will be unad in either a long bunch mode to produce thermal neutrone, or in a vort bunch mode to produce Intanae hort buratn of neutrons for nuclear physica.? Th1s u111 be c pouerful extenaton of the capabllicles of the exieting nautron tee- of-flight asa. The nntential uoes of the noutrino fluxes from the atorage ing facllity are of great interast."

\section{TRIUMF Ioprovemente}

Design and development ectivities are going on ajaing at eventual replacement of the central renonatore for the cyclotron. The goal is to 1mprove the mechanical stabilicy of the rasonatore and the ability to handle then rasotely. Th1 will facilitate higher intenuity operation of the wachine.

Recently a new teot plon channel, the so-called M1l channe1, was Inntalied. It is a cero degree, high reaolucion plon eource. An rf aeparator has been put on the w9 chennel for une with the cloud nuon bean. A beam line for 70- to 100-MaV protonn 1a beinn deasened for lirotope production.

\section{SIN Ioproverente}

The noat notable change at SIN v111 be the coundwioning of the new injector cyclocron which is now baing leadied. This wil allow the old infector to run in a dedicated mode for low-enerny nuclear phyalen, and allow the new one to be a dedicated Infector. The new Injector holde promlee of reatly increaed currente, perhape as wuch os everal milliamperen at $350 \mathrm{MpV}$. In order to axplott weh currenta, now acondary bean 11nes, new targets, and new beam dumps would be required. Uge of a dump as a opallation source of neutrone, especially cold neutrung, is being conoldered. The new plon channel for blomedical studies is fust coming into operation.

\section{Kaon Factorles}

Th1s terw, rather a misnomer, la used for proton wachines In the energy region 8 to $30 \mathrm{GeV}$, which are to of far orders of nagnitude 1mprovement in average cu:'rent over existing facilitios in this energy interval.

At Log Alamog, a fast cycling aynchrocron infected with $\mathrm{H}^{-}$from LAMF has been discussed repeatedly." The Fermilab booster synchrotron has been proposed as a kaon factory.' Table I l1ata ame aynchrotron parameters given in a recent talk by Teng. The design io not very different from the booster at Fermilab, the principal difference being a doubling of the repetition rate from 15 to $30 \mathrm{~Hz}$, changes in the injection and final energles, and concomitant changes in ring diameter and rf power requirements. The higher infection energy of LAMPF ( 800 va. 200 at Fermilab) reaulte in a reduced $r f$ frequency owing (18\% vo, 174\%) and an Improvement in the canonical injection apace cliarge limit by a factor of $B$.

\section{TABLE I}

\begin{tabular}{|c|c|}
\hline Injeztion Energy & $0.8 \mathrm{GeV}$ \\
\hline Final Energy & $16.0 \mathrm{GeV}$ \\
\hline Average Current & 100.0 NA \\
\hline Repetition Rate & $30.0 \mathrm{~Hz}$ \\
\hline Magnet Bending Radiue & $82.5 \mathrm{n}$. \\
\hline Magnet Power & $2.5 \mathrm{MN}$ \\
\hline Mean Radius of RIng & $122 \mathrm{~m}$ \\
\hline Late lce & 24 cel1s DFUOFD \\
\hline Tune (v) & $8-1 / 4$ \\
\hline Protone/Pulee & $2 \times 10^{13}$ \\
\hline Spece Charge Linlt & $3.4 \times 10^{11}$ \\
\hline Injection Frequency & $50.0 \mathrm{MHz}$ \\
\hline PInel Frequeney & 59.6 MHz \\
\hline Energy Gain/Turn & $3.7 \mathrm{MeV}(\max )$ \\
\hline Paak If Voltage/Turn & $4.3 \mathrm{kV}$ \\
\hline Cavity if Lose & $v_{2} \mathrm{IN}$ \\
\hline
\end{tabular}

\section{Stratcher}

To Increase the duty factor of the avnchrotron. the baam may be tranaferrad to a de ring having the aamp clrcumference and inatalled in the eynchrotron tunnel. Th1e ring could very well une auperconilucting mannate. $H^{-}$bean Infection Into the evnchrotron wnuld requite. now, hish-current, hish-b-lphenese $H^{2}$ mource. Such cource in now belng daveloped for the proton otorape ring by R. Stevena at Lan Alamon, baned on the work of Fhlern and loung' ot l.pL. Another requirenent for both the atorage ring and for a muchrotron in to accelerate 
simultaneously with minimal losses beams of $\mathrm{H}^{-}$anc $\mathrm{H}^{-}$ In the linac. Up to now the procedure has been to tine for best transmission of the $\mathrm{H}^{+}$beam and to accept some losses in the $H$ beam. Obviously, beam loss in the synchrotron is also a much more serious probiem for 9 kaon factory than for a booster.

At Vancouver, sume of the TRIUMF staf $f$ have been studying accelerators which, using the present cyclotron as an injector, would produce baams of 8 to $20 \mathrm{GeV}$. The CANUCK scheme envisages a $3-\mathrm{GeV}$ ring cyclotron and an 8.5-GeV ring cyclotron in serles, probably etuploy tng superconducting magnets. The current would be $400 \mu \mathrm{A}$. Another scheme would use a fast cycling synchrotion with a final energy of $20 \mathrm{GeV}$. Still ancther posstb1lity being studied is a rapld cycling $3-\mathrm{GeV}$ booster infecting into a slow cycling synchrotron with final energy $20 \mathrm{GeV}$. The final currents suggested are $200 \mu \mathrm{A}$, certainly an impressive number! R. Wilson independently suggested a superconducting synchrotron.'

All of these designs w11l have to deal with questlons of beam loss and oeam diagnostics and control very carefully irdeed.

For al: of these 3 tudies, there are also outstantIng quest10.1s abuut the fac1lity which react bach on the tesign of the accelerator. Some of these questions are:

1) Wha should be the final onergy? Whethar to nursue antiproton physics, the mater of facility cjot, the energy dependence of the production crcss sectlons for kaons, antiprotons, ete., ent $s$ into this decision. More experiments on pronduction cross sections would be very useful. If there are to be $\bar{p}$ beams, how many and what kind?

2) How may kinds of $k$ beams and what kind should there be?

3) Should polarized proton beams be provided?

4) Are targeting oystems to be sertal-parallel as at LAMPF, or parallel as at most large proton synchrotrons?

5) How can one make much brighter and higher purlty secondary and tertary (e.g., Ko beama?)

6) What high reaulition faclities for nuclear phyalen should be providet?

\section{Conclusion}

In general, tha pion factories hava lived up to the expectationa for them with renpect to thelr performance a acceleratorn and ti. Ir output of intereating resulth on the physics of partiries and of the nicleus. intereat In "kaon factorlen." seen as an extenation of the plon factorien, 1s prenently very high, both a to accelerator dentan and as co factlity and exierimental program plenning.
In 1975 , R. R. Wilson called my attention to the Fermilab booster's capab1lities. On the subject of fast-cycling synchrotrons, conversations with Lee Teng, R. R. Wilson, C. Owen, B. Brown, C. Hovjat, C. Schmidt, and $Q$. Kearns have been extremely helpful. Conversatjons with M. Craddock about the TRIUMF program have been very useful.

\section{References}

1. See, for example, "H1gh Energy Phys1cs and Nuclear Structure," D. P. Measday and A. W. Thomas, NorthHolland Publishing Company (1980); Workshop on Nuclear Structure with Intermedlate-Energy Probes, L08 Alamo8, New Mexico (January 14-16, 1980), Los Alamos National Laboratcry report LA-8303-C; LAM?F Workshop on S1ngle Plon Exchange (January 22-24, 1979), Los Alamos National Laboratory report LA-7892-C; "Theory of Meson Interactions with, Nuclel," J. Elsenberg and D. Koltun, John Wiley and Sons, New York (1980).

2. G. Lawrence et al., Proceedings of the Ilth International Conference on H1gh Energy Accelerator CERN, Ceneva, Swltzerland, p. 103 (July 1980).

3. "Study of Uses of a Proton Storage Ring." D. Nagle ed. " Los Alsmos National Laboratory report LA-7490MS (1978); Proceed1ngs on Worksirsp on Program Options in Intermediate Erergy Thysics, J. Allred and B. Talley, eds., Vol. I, P. 41 (1979), Los Alamos National Laboratory report LA-8335-C.

4. D. Nagle, Preceedings of the Kaon Factory horkshop, Vancouver, B.C. (August 1?-14, 1979), M. K. Craddock ed., (TRI-79-1) p. 197.

5. B. Brown and C. Hofvat, 1b1d, p. 178; aee also Yu G. Basargin et a1., Dok1. Acad. Nauk SSR 20S, ¿82 (1976).

6. L. C. Teng, Proceedings Workshop on Nuclear and Particle Phyalce at Energies up to $31 \mathrm{GeV}$, Los Alamos National Laboratory, Los Alamos, New Mexico (January 1981), Lon Alamos National Laboratory

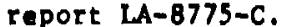

7. K. W. Ehlere and Leung, LBL-10013.

8. M. K. Craddock, C. J. Koat, and J. R. R1chardson, Proceedinge on the Keon Factory Workshop. Vancouver. B.C. (1979), M. X. Craddock, ed., (TRI-79-1), p. 185; J. R. Richardeon and M. K. Craddock, private colamunication.

9. R. R. Wilmon, private communication.

10. Proceedinge on the Workohop on Nuclar and Partlcle Phyalce at Energien up to $31 \mathrm{GeV}$, Los Alamon Nationd1 Lajoratory, Lo Alamon, New Mexico (January 1981). Los . Ilemos Netional Leboratory report LA-8775-C. 